\title{
Evaluation of Engineering Properties of Plastic Modified Bitumen
}

\author{
Jwala Bishnoi, Vikram Dhillon and Himanshu Monga* \\ Jan Nayak Chaudhary Devi Lal Memorial College of Engineering, Sirsa - 125055, Haryana, India; \\ arshitabishnoi@gmail.com,vdvikramdhillon32@gmail.com,himanshumonga@gmail.com
}

\begin{abstract}
Objectives: To make an efficient utilization of waste plastics for pavement construction stronger, economical and ecofriendly. Methods/Statistical Analysis: Comparative experimentations are carried out on three sets of samples: pure bitumen \& modified bitumen, conventional mix\& modified bituminous mix and uncoated aggregates \& plastic coated aggregates. Modified bitumen is prepared by mixing powder ground plastic ( $10 \%$ by weight of bitumen) in pure bitumen. Dry mix process is employed to prepare plastic coated aggregates and modified bituminous mix. Findings: The experimentations result showed that the modification of conventional bitumen with waste plastic shows positive margin in all the tests carried out except ductility test. The conventional roads are constructed using bitumen, which is not only expensive but also have some pre and post constructional problems like rutting, potholes, stripping out of aggregates, etc. This work justified the utilisation of waste plastic as a partial substitute of bitumen in which the extent of replacement of bitumen with waste plastic is $10 \%$ by weight of bitumen. Waste plastic not only reduces the cost but also improves constructional features such as reduced rutting as it increases the softening point and reduces cracking and pothole as loss on heating of modified bitumen is less. Application/Improvements: In binding and surface courses of pavement bitumen can be successfully replaced with $10 \%$ of waste plastic to impart greater strength and durability to the pavement.e.
\end{abstract}

Keywords: Bitumen, Conventional Mix, Modified Mix, Pavement, Waste Plastic

\section{Introduction}

For development of every nation connectivity is the basic necessity. Connectivity is ensured by road construction. With increasing traffic, the high strength pavements are becoming the need of the hour. But the conventional bituminous roads are unable to perform well and bear such a huge traffic. The problems such as rutting, pothole formation, cracking, etc. are common with conventional bituminous roads. On the other side, plastic is now becoming an integral part of our life. In India as per reported by Mr. Dave, our environment minister, "Central Pollution
Control Board has estimated the generation of 15,342 tonnes of plastic waste in the country, out of which, 9,205 tonnes were reported to be recycled and leaving 6,137 tonnes uncollected and littered. The lack of awareness and absence of effective tools to collect back the discarded plastic products including the wrapping material has led to the indiscriminate littering and disposal of plastic waste. $\frac{1}{}$ Thus plastic imposes giant disposal problem. So, if we see these two problems simultaneously they can serve as solution to one-another i.e. we can use waste plastic as a partial substitute of bitumen which improves the level

*Author for correspondence 
of serviceability provided by the road, imparts better binding, increases strength and service life of pavement, makes road construction economical and avoids disposal problem of plastic waste.

In the reported article concluded from their investigation that the pavement constructed after modification in bitumen binder with waste plastic showed better moisture resistance which is justified from reduction in stripping of plastic coated aggregate as compared to uncoated aggregates. ${ }^{2} \mathrm{He}$ also stated that the concept of utilization of waste plastic in the construction of pavement has made see off to the disposal problem of waste plastic, as it is a finest way to reuse the plastic waste ecologically.

In the article studied the effect of addition of plastic in bitumen, on its stability, life and strength. All of them showed positive results, that plastic addition improves stability, enhances strength and increases life when added in bitumen. $\underline{3}$

In the article performed thin film oven test and reported less ageing of plastic bitumen blends in comparison with the neat bitumen. ${ }^{4}$ This justified better performance of the blend and build resistance to cracking. This is the reason due to which less premature failures are observed on the pavements made with modified bitumen with plastic bend. Other characteristics are also improved such as: the plastic blend in bitumen has improved indirect tensile strength and better rutting resistance as compared to conventional bituminous mix. For checking moisture resistance Stripping test was conducted after proper mixing. The test inferred that the adhesion of the stone-plastic waste-bitumen aggregate was good. Tar road is performing efficaciously great when laid, when diversified with stone and bitumen at high speed asphalt plant.

In the article studied chemically modified polyethylene and find characteristics of partial asphalt substitute in them, so that it can be used as paving materials. 5 Chemically grafted polymers are readily miscible with asphalt. The blend thus prepared have increased softening point, decreased degree of penetration, improved performance at higher temperatures, better rutting resistance and high flow activation energy.

\section{Present Investigations}

The conventional bitumen roads can be economically and structurally improved by using waste Plastic, which can serve two purposes which are safe disposal of waste plastic and economized roads with enhanced characteristics. Method of construction of plastic blended pavement is similar to the flexible pavement construction the only processes vary are pre-construction processes which are as follows:-

\subsection{Segregation}

Waste plastic in the form of plastic carry bags, disposal cups, PET bottles, etc. are collected from roads, garbage trucks, municipal offices and compost plants, rag pickers and segregated from other wastes.

Segregation of waste plastic includes following steps:

- The waste plastic is separated out from other wastes.

- Then from different forms of plastic wastes i.e. PET, HDPE, LDPE, etc. PVC and Other plastic wastes are discarded as they release lethal products on burning.

- Now the collected Plastic forms are sorted as per the required thickness. Generally, polyethylene of 60 micron or below is used for the further process due to the fact that less micron plastic is easily mixable in the bitumen at higher temperature $\left(160^{\circ} \mathrm{C}-170^{\circ} \mathrm{C}\right)$.

\subsection{Cleaning}

The segregated plastic is then cleaned by de-dusting or washing if required. Generally water washing is used for cleaning them. Washing is done by blowing streams and then the washed plastic is allowed to dry for further processing. Sometimes de-coloring is also adopted to remove harmful colors and improve characteristics of the blend. 


\subsection{Shredding and Collection}

Cleaned Plastic is shredded into fine pieces by shredding machine. The shredded plastic pieces are sieved. The shredded plastic passing through $4.75 \mathrm{~mm}$ sieve and retaining at $2.36 \mathrm{~mm}$ sieve are collected.

\subsection{Field Trials}

In field it can be processed by two processes viz. Dry Process and Wet Process. In this document dry process is evaluated, as it is easy to go through dry process where as the wet process needs central mixing plant with heavy mixing equipments.

\subsubsection{Field Trial for Dry Process ${ }^{6}$}

- The aggregates of different grading are mixed thoroughly.

- Then the aggregates are heated to a temperature of $165-170^{\circ} \mathrm{C}$.

- That temperature is maintained for 2-3 minutes.
- Then the shredded plastic of required size is added in equal proportions and mixed to obtain a homogeneous mix.

- Then hot bitumen is added to the plastic coated aggregates. The mix is then laid for constructing pavement similar to the mix used in conventional pavements.

\section{Performance Evaluations}

For testing the effect of waste plastic the tests are carried on over: Plastic coated aggregates and Modified Bitumen (with $90 \%$ bitumen and 10\% plastic by weight) and Modified Bituminous mix.

- Test over Modified bitumen: Tests such as penetration test, ductility test, softening point test, flash and fire point test and loss on heating test are carried out on both pure bitumen and modified bitumen for comparing the results to draw the effect of addition of waste plastic. Table 1 shows the results of test over bitumen.

Table 1. Result of tests on bitumen

\begin{tabular}{|c|c|c|c|}
\hline Name of the test & Specification & Result (t) & Guideline Followed \\
\hline \multirow{2}{*}{ Penetration Test } & Pure Bitumen & $87 \mathrm{~mm}$ & \multirow{2}{*}{ IS 1203: 1978} \\
\hline & $\begin{array}{c}\text { Bitumen with } 10 \% \text { waste plastic by } \\
\text { weight of bitumen }\end{array}$ & $59 \mathrm{~mm}$ & \\
\hline \multirow{2}{*}{ Ductility Test } & Pure Bitumen & $82 \mathrm{~cm}$ & \multirow[b]{2}{*}{ IS 1208: 1978} \\
\hline & $\begin{array}{c}\text { Bitumen with } 10 \% \text { waste plastic by } \\
\text { weight of bitumen }\end{array}$ & $49 \mathrm{~cm}$ & \\
\hline
\end{tabular}


Table 1 Continued

\begin{tabular}{|c|c|c|c|}
\hline \multirow{2}{*}{ Softening Point Test } & Pure Bitumen & $46^{\circ} \mathrm{C}$ & \multirow{2}{*}{ IS 1205: 1978} \\
\hline & $\begin{array}{c}\text { Bitumen with } 10 \% \text { waste plastic by } \\
\text { weight of bitumen }\end{array}$ & $63{ }^{\circ} \mathrm{C}$ & \\
\hline \multirow{2}{*}{ Flash Point Test } & Pure Bitumen & $250{ }^{\circ} \mathrm{C}$ & \multirow{2}{*}{ IS 1209: 1978} \\
\hline & $\begin{array}{c}\text { Bitumen with } 10 \% \text { waste plastic by } \\
\text { weight of bitumen }\end{array}$ & $288^{\circ} \mathrm{C}$ & \\
\hline \multirow{2}{*}{ Fire Point Test } & Pure Bitumen & $292{ }^{\circ} \mathrm{C}$ & \multirow{2}{*}{ IS 1209: 1978} \\
\hline & $\begin{array}{c}\text { Bitumen with } 10 \% \text { waste plastic by } \\
\text { weight of bitumen }\end{array}$ & $332{ }^{\circ} \mathrm{C}$ & \\
\hline \multirow{2}{*}{ Loss on heating Test } & Pure Bitumen & $0.309 \%$ & \multirow{2}{*}{ IS 1212: 1978} \\
\hline & $\begin{array}{c}\text { Bitumen with } 10 \% \text { waste plastic by } \\
\text { weight of bitumen }\end{array}$ & $0.210 \%$ & \\
\hline
\end{tabular}

- Penetration Test: ${ }^{\mathbb{Z}}$ Grading of bitumen is done on the basis of its consistency. The consistency is determined by the penetration value. To get the penetration value the Penetration test is carried out as per the guidelines of IS 1203-1978. Penetration value it is the distance travelled by the standard needle of specific shape, size and weight under specified conditions of time and temperature in one-tenth of millimeters.

- Ductility Test: $: \frac{8}{}$ Ductility is the property of binding material which allows it to undergo great deformation or elongation without breaking. It is expressed in cms of distance to which the standard sample of material can undergo elongation without breaking. This test is carried out as per the IS: 1208-1978 guidelines.

- Softening Point Test: ${ }^{9}$ Softening point refers to the degree of temperature at which the sample achieves specific grade of softness. Higher softening point induces lower temperature susceptibility. To specify temperature susceptibility softening point is tested as per the specifications of IS: 12051978. 
- Flash and Fire Point: $\frac{10}{}$ Flash and fire point test are to check the qualification of standard sample. At high temperatures bitumen material releases volatile which momentarily catches fire? This becomes hazardous if used as paving material. So, it is essential to check the flash and fire point temperature as per the guidelines of IS: $1209-1978$, if it is to be used in hot regions.

- Loss on Heating Test: $\underline{11}$ This test is carried out as per specifications of IS: $1212-1978$ to show the quality of bitumen which is to be used as paving material. On heating bitumen releases volatile and loses its mass, if this mass is more than $1 \%$ then the sample is discarded.

- Test over Modified Mix: Marshall Stability and flow value test are carried out on conventional bituminous mix and modified bituminous mix. Table 2 shows the results of Marshall Test for both conventional as well as modified bituminous mix.

- Marshall Stability Test: $\frac{12}{2}$ Marshall Stability is expressed as the resistance to the plastic defor- mation of cylindrical specimen of bituminous mix when it is loaded at its periphery at the rate of $5 \mathrm{~cm} / \mathrm{min}$. Marshall Stability test is carried out, as per the guideline of SP 53-1999 and ASTM D 1559-1979 to evaluate the mix design to be used in pavement construction. This is the most important test governing the strength of mix.

- Test over aggregates: plastic coated aggregates and uncoated or pure aggregates are tested for impact value and stripping value and their results are recorded in Table 3.

- Stripping Test: $\underline{\underline{13}}$ Stripping test is performed to check whether the aggregate remain bound to the binder when subjected to water or immersed in water. It is visual evaluation test that due to water to what extent the binder coating is stripped out. This test is carried out as per to check the moisture susceptibility.

- Aggregate Impact Value Test: $\stackrel{14}{ }$ Aggregate impact value is the measure of toughness of aggregates. Aggregate when used in pavements undergo

Table 2. Result of tests on bitumen

\begin{tabular}{|c|c|c|c|}
\hline Name of the Test & Specification & Result & Guideline Followed \\
\hline \multirow{2}{*}{ Marshall stability Test } & Conventional Bituminous mix & $610 \mathrm{Kg}$ & \multirow{2}{*}{$\begin{array}{l}\text { IRC SP 53-1999 and } \\
\text { ASTM D 1559-1979 }\end{array}$} \\
\hline & $\begin{array}{l}\text { Modified Bituminous mix with } \\
10 \% \text { waste plastic }\end{array}$ & $985 \mathrm{Kg}$ & \\
\hline \multirow{2}{*}{ Marshall Flow Test } & Conventional Bituminous mix & $8.3 \mathrm{~mm}$ & \multirow{2}{*}{$\begin{array}{l}\text { IRC SP 53-1999 and } \\
\text { ASTM D 1559-1979 }\end{array}$} \\
\hline & $\begin{array}{l}\text { Modified Bituminous mix with } \\
10 \% \text { waste plastic }\end{array}$ & $11.1 \mathrm{~mm}$ & \\
\hline
\end{tabular}


Table 3. Result of tests on Aggregates

\begin{tabular}{|c|c|c|c|}
\hline \multirow{2}{*}{ Name of the Test } & Specification & Result (\%) & Guideline Followed \\
\hline \multirow{2}{*}{ Impact Value test } & Pure aggregate & 5 & \multirow{2}{*}{ IS 2386 (Part-IV)-1963 } \\
\cline { 2 - 3 } & Plastic coated aggregate & 4 & \\
\hline \multirow{2}{*}{ Stripping Test } & Pure aggregate & 8 & IS 6241 \\
\cline { 2 - 4 } & Plastic coated aggregate & Nil & \\
\hline
\end{tabular}

impact of moving traffic which crushes the aggregates in small pieces which is determined prior to its application through aggregate impact value test specifications by IS 6241 .

\section{Conclusion}

In construction of pavement, bitumen is used in binding course and surface course. It can be successfully replaced from waste plastic by $10 \%$ by weight of bitumen. As it enhances the characteristics of bitumen by improving its engineering properties. By doing so we can save huge sum of the nation in construction (per kilometre of pavement stretch). This is an innovative approach to dispose highly pollutant material, waste plastic, in most beneficial and ecological way which not only results in improved pavement material in surface courses but also, make it economical and durable and helps in keeping environment healthy and clean.

\section{References}

1. Business Standard Report [Internet]. [updated 2016 Aug 2]. Available from: http://www.business-standard.com/ article/pti-stories/15-342-tn-plastic-waste-generated-inindia-everyday-dave-116080200866_1.html
2. Khandekar SD, Sasane NB, Harish G, Patil JR. Application of Waste Plastic as an Effective Construction Material in Flexible Pavement. International Research Journal of Engineering and Technology (IRJET). 2015; 2(3):1943-8.

3. Justo CEG, Khanna SK. Highway Engineering. Design of highway Pavement. Nem Chand \& Bros Publication: India; 2015. p. 339-80.

4. Sharma HK. Utilization of Waste Plastic in Construction of Pavement. International Journal of Advance Engineering and Research Development (NCRRET); 2015. p. $1-5$.

5. Vargas MA, Solis As, Manero O. Asphalt/polyethylene blends: Rheological properties microstructure and viscosity modelling. Journal of Construction and Building Materials. 2013; 45:243-50. Crossref.

6. SP 098. Guidelines for the Use of Waste Plastic in Hot Bituminous Mixes (Dry Process) in Wearing Courses. Indian Road Congress: New Delhi; 2013.

7. IS 1203. Methods of testing tar and bituminous material: Determination of penetration. Bureau of Indian Standards: New Delhi; 1978.

8. IS 1208. Methods of testing tar and bituminous material: Determination of ductility. Bureau of Indian Standards: New Delhi; 1978.

9. IS 1205. Methods for testing tar and bituminous materials: Determination of softening point. Bureau of Indian Standards: New Delhi; 1978. 
10. IS 1209. Methods for testing tar and bituminous materials: Determination of Flash Point and Fire Point. Bureau of Indian Standards: New Delhi; 1978.

11. IS 1212. Methods for testing tar and bituminous materials: Determination of Loss on Heating. Bureau of Indian Standards: New Delhi; 1978.

12. ASTM D 1559. Standard Test Method for Resistance to Plastic Flow of Bituminous Mixtures Using Marshall Apparatus. American Society for testing and materials; 1973.
13. IS 6241. Method of Test for Determination of Stripping Value of Road Aggregates. Bureau of Indian Standards: New Delhi; 1971.

14. IS 2386 Part-IV. Methods of test for aggregate for concrete. Part IV: Mechanical Properties. Bureau of Indian Standards: New Delhi; 1963. 